\title{
Calcium Imaging of Nerve-Mast Cell Signaling in the Human Intestine
}

\section{Sabine Buhner ${ }^{1}$, Natasja Barki ${ }^{1}$, Wolfgang Greiter ${ }^{1}$, Pieter Giesbertz ${ }^{2}$, Ihsan E. Demir ${ }^{3}$, Güralp O. Ceyhan ${ }^{3}$, Florian Zeller ${ }^{4}$, Hannelore Daniel ${ }^{2}$ and Michael Schemann ${ }^{1 *}$}

${ }^{1}$ Human Biology, Technische Universität München, Freising, Germany, ${ }^{2}$ Molecular Nutrition Unit, Technische Universität München, Freising, Germany, ${ }^{3}$ Department of General Surgery, University Hospital Rechts der Isar, Technische Universität München, Munich, Germany, ${ }^{4}$ Surgery, Academic Hospital Freising, Freising, Germany

Introduction: It is suggested that an altered microenvironment in the gut wall alters communication along a mast cell nerve axis. We aimed to record for the first time signaling between mast cells and neurons in intact human submucous preparations.

Methods: We used the $\mathrm{Ca}^{2+}$ sensitive dye Fluo-4 AM to simultaneously image changes in intracellular calcium $\left[\mathrm{Ca}^{+2}\right]_{\mathrm{i}}(\% \Delta \mathrm{F} / \mathrm{F})$ in neurons and mast cells. Data are presented as median with interquartile ranges (25/75\%).

Results: We recorded nerve responses in 29 samples upon selective activation of 223 mast cells by lgE receptor cross linking with the antibody mAb22E7. Mast cells responded to mAb22E7 with a median $\left[\mathrm{Ca}^{+2}\right]_{i}$ increase of $20 \%(11 / 39)$ peaking $90 \mathrm{~s}(64 / 144)$ after the application. Only very few neurons responded and the median percentage of responding neuronal area was $0 \%$ (0/5.9). Mast cell activation remained in the presence of the fast sodium channel blocker tetrodotoxin. Specific neuronal activation by transmural electrical field stimulation (EFS) in 34 samples evoked instantaneously $\left[\mathrm{Ca}^{+2}\right]_{\mathrm{i}}$ signals in submucous neurons. This was followed by a $\left[\mathrm{Ca}^{+2}\right]_{\mathrm{i}}$ peak response of $8 \% \Delta F / F(4 / 15)$ in $33 \%$ of 168 mast cells in the field of view. The mast cell response was abolished by the nerve blocker tetrododoxin, reduced by the Calcitonin Gene-Related Peptide receptor 1 antagonist BIBN-4096 and the Vasoactive Intestinal Peptide receptor antagonist PG97-269, but not by blockade of the neurokinin receptors 1-3.

Conclusion: The findings revealed bidirectional signaling between mast cells and submucous neurons in human gut. In our macroscopically normal preparations a nerve to mast cell signaling was very prominent whereas a mast cell to nerve signaling was rather rare.

Keywords: enteric nervous system, neuropeptides, $\mathrm{Ca}^{2+}$ imaging, neuro-immune, CGRP, SP, VIP, human gut

\section{INTRODUCTION}

The gut has two unique features. It is the largest immune competent organ in our body and it harvests an enormous number of nerves. Most of the nerve structures belong to the enteric nervous system (ENS) which regulates gut functions autonomously. The remaining extrinsic nerves connect the central nervous system with the gut and belong either to the afferent gut-brain or the efferent brain-gut axis. Both the sensory as well as the motor pathways ramify extensively once entering the gut wall. The ENS consists of two ganglionated plexus: the myenteric plexus between the two 
outer muscle layers and the submucous plexus close to the mucosa. The enteric immune system is an effective defense system maintaining a functional barrier and thus protecting the host from harmful invaders and noxious substances. Conceptually, it is important to realize that all three systemsENS, extrinsic nerves, and enteric immune system-enter into an intimate anatomical and functional association (Margolis et al., 2016). Over the years, mast cells (MCs), have received a lot of attention as an important player for neuroimmune interactions in the gut. They are located primarily in perivascular spaces, $\sim 2-3 \%$ of all cells in the lamina propria and about $1 \%$ of all cells in the submucosa (Bischoff et al., 1996) are MCs. Deeper layers almost lack MCs under normal conditions (Buhner and Schemann, 2012; Schemann and Camilleri, 2013). An estimated $90 \%$ of intestinal mucosal MCs are located at least within $2 \mu \mathrm{m}$ (Stead et al., 1989; Dvorak et al., 1992).

There is strong evidence for nerve-MC interaction, particularly in diseases such as food allergy (Bischoff et al., 2000; Torrente et al., 2014), inflammatory bowel disease (IBD; Dvorak et al., 1978; Raithel et al., 2001), and irritable bowel syndrome (IBS; Pang et al., 1996; Schemann and Camilleri, 2013). Often, these conditions are accompanied by an increase in number and/or activity of MCs as for example in IBS (Barbara et al., 2004, 2007; Guilarte et al., 2007). Most of the studies on nerve-MC signaling focused on experiments in cell culture and rodent animal models (De Jonge et al., 2004; Furuno et al., 2004; Bell et al., 2015). These studies also proposed Substance P (SP) (Furuno et al., 2004) and Calcitonin Gene-Related Peptide (CGRP; De Jonge et al., 2004) as mediators for nerve to MC signaling. Animal studies supported an active role of MC to nerve signaling in colonic secretory responses to antigen application in sensitized rats (Bell et al., 2015) or mice (Perdue et al., 1991) and enhanced excitability of submucous neurons in sensitized guinea pigs (Frieling et al., 1994). One study showed in guinea pig ileum and colon a functional extrinsic nerve-MC-ENS pathway based on the finding that stimulation of extrinsic nerves caused release of MC proteases which in turn activated submucous neurons through the protease activated receptor (PAR) 1 and PAR2 (Wang et al., 2014). Stimulation of afferent nerves in human intestine released, besides SP and CGRP (Wang et al., 2014) also Vasoactive Intestinal Peptide (VIP) (Maggi et al., 1989).

It is striking that the concepts on nerve-MC interactions have never been demonstrated at a cellular level in intact tissue preparations and even more await validation in the human gut. At functional and molecular levels, extrapolation from animal models is problematic because MCs as well as enteric neurons exhibit species-specific features of release mechanisms, mediator profile, and neuropharmacology (Bischoff, 2007; Buhner and Schemann, 2012). For example in cultured human intestinal MCs exogenous application of neurotransmitters did not cause mediator release under basal conditions (Bischoff et al., 2004).

Abbreviations: IBS, irritable bowel syndrome; IBD, inflammatory bowel diseases; ENS, enteric nervous system; $\left[\mathrm{Ca}^{2+}\right]_{\mathrm{i}}$, intracellular calcium-increase; TTX, tetrodoxin; CGRP, calcitonin gene-related peptide; VIP, vasoactive intestinal peptide; VPAC, vasoactive intestinal peptide receptor; SP, substance P; NK, neurokinin.
However, MCs started to express neurokinin receptors after exposure to growth factors or IL4 (Bischoff et al., 2004). Thus, the plasticity of cultured MCs may have compromised expression of relevant receptors. Development, differentiation, and functional reactivity of MCs are critically dependent on the microenvironment (Bischoff, 2007). MCs are extremely plastic and adapt synthesis and release of their mediators to tissue conditions. All the above suggest that investigation of bidirectional communication between MCs and enteric neurons require recording of their activity in intact tissue where both cell types experience their physiological milieu.

We previously demonstrated that the mast cell mediators histamine and tryptase as well as a mediator cocktail release from human intestinal mast cells upon IgE receptor crosslinking by mAb22E7 activated human submucous neurons (Schemann et al., 2005; Breunig et al., 2007; Ostertag et al., 2017).

To our knowledge, direct recordings of neve-MC communication has not been performed and certainly not in intact human intestinal preparations. Therefore, the overall goal of the present project was to study nerve-MC signaling in submucous plexus preparations from human intestine. We used the submucous layer as the density of mast cells was highest in this region (Buhner and Schemann, 2012; Schemann and Camilleri, 2013). After selective stimulation of MCs or neurons we used $\left[\mathrm{Ca}^{+2}\right]_{\mathrm{i}}$ imaging to record subsequent cell activation. The participation and role of particular mediators involved in the signaling pathway were identified pharmacologically. We could show for the first time nerve-MC interaction on a cellular level in intact human submucous plexus.

\section{METHODS}

\section{Human Tissue Samples}

All studies on nerve and MC activity were performed using surgical specimens of human colon $(n=46)$, ileum $(n=23)$, jejunum $(n=12)$, or duodenum $(n=2)$, obtained from 83 patients (39 females, 44 males; mean age 64 years (range 29-88 years) undergoing abdominal surgery at the Medical Clinic in Freising and the Medical Clinic of the Technische Universität München. Diagnoses that led to the surgery were as follows: carcinomas of large intestine (53), stomach (4), appendix (1), pancreas (10), adrenal gland (1), or fat tissue (1), diverticular disease (1), polyposis (2), stoma relocation (2), abdominal abscess (2), stenosis (2); fistula (1) and unspecified bleeding (1) and unspecified reasons (2). Samples were taken from macroscopically normal, unaffected areas as determined by visual inspection by the pathologists. The protocol was approved by the ethics committee of the Technische Universität München (project approval 5242/11). Informed written consent was obtained from all subjects, and the studies conformed to the standards set by the Declaration of Helsinki. After removal, the surgical specimens were placed in cold aerated sterile HEPESKrebs solution containing in mM: $135 \mathrm{NaCl}, 5.4 \mathrm{KCl} ; 1.0 \mathrm{Mg}$ $\mathrm{Cl}_{2} \cdot 6 \mathrm{H}_{2} \mathrm{O}, 1.2 \mathrm{NaH}_{2} \mathrm{PO}_{4}, 1.25 \mathrm{CaCl}_{2} \cdot 2 \mathrm{H}_{2} \mathrm{O}, 12.2$ Glucose, and 3 HEPES (all from Sigma-Aldrich Chemie GmbH, Darmstadt, Germany) and $10 \mathrm{ml} / \mathrm{l}$ antibiotic-antimycotic $\mathrm{mix}$ (mg/L: 25 amphotericin B, $107 \mathrm{U} / \mathrm{L}$ penicillin $\mathrm{G}, 10,000$ streptomycin in 
physiological saline; CCPro, Oberdorla, Germany). They were immediately transported to the laboratory for experiments. Under continuous superfusion with ice-cold carbogen-aerated Krebs solution containing in mM: $117 \mathrm{NaCl}, 4.7 \mathrm{KCl}, 1.2$ $\mathrm{MgCl}_{2} \cdot 6 \mathrm{H}_{2} \mathrm{O}, 1.2 \mathrm{NaH}_{2} \mathrm{PO}_{4}, 25 \mathrm{NaHCO}_{3}, 2.5 \mathrm{CaCl}_{2} \cdot 2 \mathrm{H}_{2} \mathrm{O}$ and 11 glucose (all from Sigma), the surgical specimens were microscopically dissected by removing the mucosa and the muscular layers to obtain a whole mount preparation of the inner submucosal plexus. The final preparations $(10 \times 20 \mathrm{~mm})$ were pinned on silicone rings (Buhner et al., 2009).

\section{Calcium Imaging of MC and Neuronal Activity}

The fluorescent calcium indicator Fluo 4-acetoxymethyl (AM) (Invitrogen, Darmstadt, Germany) was used to monitor changes in intracellular calcium $\left(\left[\mathrm{Ca}^{2+}\right]_{i}\right.$; Michel et al., 2011). As previously described in detail (Ostertag et al., 2017) the submucous plexus preparations were incubated at room temperature in the dark with $10 \mu \mathrm{M}$ Fluo- $4 \mathrm{AM}$ for $45 \mathrm{~min}$ and subsequently washed for $20 \mathrm{~min}$. For incubation, washing, and superfusion during the experiments a carbogen-aerated Krebs buffer $\left(117 \mathrm{NaCl}, 4.7 \mathrm{KCl}, 1.2 \mathrm{MgCl}_{2} \cdot 6 \mathrm{H}_{2} \mathrm{O}, 1.2 \mathrm{NaH}_{2} \mathrm{PO}_{4}\right.$, $20 \mathrm{NaHCO}_{3}, 2.5 \mathrm{CaCl}_{2} \cdot 2 \mathrm{H}_{2} \mathrm{O}$ and 11 glucose) containing $500 \mu \mathrm{M}$ probenecid (Sigma-Aldrich) to prevent dye leakage, was used.

The preparations were then placed in a recording chamber, superfused with $37^{\circ} \mathrm{C}$ Krebs solution (perfusion rate $8.5 \mathrm{ml} / \mathrm{min}$ ) and mounted on an inverted epifluorescence microscope (Zeiss Axio Observer A1, Carl Zeiss, Jena, Germany) equipped with a high speed monochrome camera (Zeiss AxioCam HSm) and software (Zeiss Axio Vision 4.8) for acquisition and analysis. Fluo-4 AM was excited using a blue light emitting diode (LED) Luxeon III ( $3 \mathrm{~W}, 470 \mathrm{~nm}$ dominant wavelength, Philips Lumiled, Phillips, Hamburg, Germany) and the signals were detected with a filter cube F26-514 Bright Line FITC BP (excitation: HC475/35, dichroic: 499, emission: HC530/43, AHF Analysentechnik, Tübingen, Germany) using 20x objective (APlan, NA $=0.25$, Zeiss) (Nemethova et al., 2013). The system measured relative changes in fluorescence $(\Delta \mathrm{F} / \mathrm{F})$ of Fluo- $4 \mathrm{AM}$ monitoring changes in $\left[\mathrm{Ca}^{2+}\right]_{\mathrm{i}}$.

\section{Stimulation of MCs and Neurons}

Depending on the stimulus, $\left[\mathrm{Ca}^{+2}\right]_{\mathrm{i}}$ transients were recorded for $45 \mathrm{~s}$ up to $370 \mathrm{~s}$ using a frame rate of $0.5 \mathrm{or} 1 \mathrm{~Hz}$. Under basal condition the variation in background fluorescent was $\pm 1 \% \Delta \mathrm{F} / \mathrm{F}$. A three-fold standard deviation (3\%) was defined as threshold for genuine cell activation. Basal, non-stimulated $\left[\mathrm{Ca}^{+2}\right]_{\mathrm{i}}$ transients were recorded for $45 \mathrm{~s}$ and $0.5 \mathrm{~Hz}$.

We selectively stimulated the MCs by IgE receptor cross linking using a monoclonal antibody (mAb) 22E7 to the highaffinity IgE receptor (Fc epsilon RI) (Riske et al., 1991). MAb 22E7 was generously supplied by Genentech-Roche, San Francisco, US. A $1 \mathrm{ml}$ syringe was filled with $10 \mu \mathrm{g} / \mathrm{ml}$ of the antibody in order to locally perfuse an area of $0.05 \mathrm{~mm}^{2}$ (corresponding to $66 \%$ of the total field of view using the $\mathrm{x} 20$ objective) containing one submucous ganglion and mast cells located nearby. According to our previous studies using spritz pulse application, a 1:10 dilution of the applied substance has to be considered for the local perfusion as well (Breunig et al., 2007). The local perfusion via a micro perfusion pump (Micro4, WPI Sarasota FL, US) lasted $60 \mathrm{~s}$ at a speed of $0.1 \mu \mathrm{l} / \mathrm{s}$.

To confirm that mAb22E7 is able to cause MC degranulation we incubated human submucous plexus preparations (size of $\left.5 \mathrm{~mm}^{2}\right)$ either with mAb22E7 $(10 \mu \mathrm{g} / \mathrm{ml})$ for $60 \mathrm{~s}$ or in Krebs buffer alone (control). After $60 \mathrm{~s}$ the supernatants were immediately removed and filtered $(0.2 \mu \mathrm{m})$. Supernatants and tissues were stored at $-80^{\circ} \mathrm{C}$. We quantified the histamine concentrations in both the supernatants and the tissues using liquid chromatography tandem-mass spectrometry (targeted LCMS/MS). Ten microliters of the supernatants were mixed with $10 \mu \mathrm{l}$ of $1 \mu \mathrm{M}$ Histamine-d4 (internal standard, Santa Cruz Biotechnology, Heidelberg, Germany), subsequently dried in a SpeedVac vacuum concentrator. The tissue samples were first dissolved in $30 \%$ methanol, homogenized, sonicated for $10 \mathrm{~min}$ and centrifuged $(13,000 \mathrm{~g}$ for $10 \mathrm{~min})$. Four hundred and sixty microliters of the liquid extract was then mixed with $10 \mu \mathrm{l}$ of $1 \mu \mathrm{M}$ Histamine-d4 and dried. Pre-column derivatisation of all samples was done using phenylisothiocyanate (PITC). Briefly, a $200 \mu \mathrm{L}$ mixture consisting of 5\% PITC dissolved in pyridine, ethanol, and $0.1 \% \mathrm{NH}_{3}$ in a $1 / 1 / 1$ ratio was added to the dried samples. Samples were shaken at $25^{\circ} \mathrm{C}$ for $20 \mathrm{~min}$ and were subsequently dried and then resuspended in methanol containing $5 \mathrm{mM}$ ammonium acetate and finally diluted with water to reach a methanol/water ratio of 70:30. The analysis was performed on a triple quadrupole QTRAP 5500 LC-MS/MS system operating in positive ESI mode (AB Sciex, Framingham, MA, USA) equipped with a 1,200 series binary pump (Agilent, Santa Clara, CA, USA) and coupled to an HTC pal autosampler (CTC Analytics, Zwingen, Switzerland). Chromatographic separation was achieved using a Zorbax Eclipse XDB-C18 column (length $150 \mathrm{~mm}$, internal diameter $3.0 \mathrm{~mm}$, particle size $3.5 \mu \mathrm{m}$; Agilent, Waldbronn, Germany). Eluent A consisted of $0.2 \%$ formic acid in water. Eluent B consisted of $0.2 \%$ formic acid in acetonitrile. Histamine was measured in scheduled multiple reaction monitoring (sMRM). For quantification, an 9-point calibration was performed $(0-50 \mu \mathrm{M})$ using pure histamine. Data analysis was done using Analyst $1.5 .1^{\circledR}$ software (AB Sciex). All results were normalized to the weight of the tissue.

We specifically stimulated the neurons in the human submucous plexus by transmural electrical field stimulation (EFS). The EFS of the nerves was achieved by two platinum electrodes and a constant voltage stimulator (Typ 215/I, Hugo Sachs Elektronik, Hayard-Apparatus GmbH, March-Hugstetten, Germany). The stimulus parameters were: $10 \mathrm{~s} 50 \mathrm{~Hz}$ pulse train with $0.5 \mathrm{~ms}$ pulse duration at $25 \mathrm{~V}$. The rather high stimulus frequency was based on early studies demonstrating maximal effects on muscle tone at a frequency of $50 \mathrm{~Hz}$ (Paton and Vane, 1963). The response to EFS did not run down. We calculated the average $\mathrm{MC}$ response index (peak $\left[\mathrm{Ca}^{+2}\right]_{\mathrm{i}}$ as $\% \Delta \mathrm{F} / \mathrm{F} \times \mathrm{x}$ responding $\mathrm{MCs}$ ) of tissues which had been stimulated with transmural EFS for at least three to eight times (6 tissues, 6 ganglia, $23 \mathrm{MCs}$ ) and compared the values with responses to the first EFS (19 tissues, 19 ganglia, $115 \mathrm{MCs}$ ). The median MC response index did not vary between these two groups [first EFS: 
235 (170/546) vs. third-eighth EFS: $560(146 / 1531)](P=0.546$, Mann-Whitney Rank Sum Test).

For pharmacological studies the following substances were added to the perfusing Krebs solution: $1 \mu \mathrm{M}$ tetrodoxin (TTX, Alexis, Lausen, Switzerland) perfused for 20 min to block nerve conduction; $10 \mu \mathrm{M}$ BIBN-4096 for 60 min (Synonym BIBN 4096BS, Tocris Bioscience Bristol, UK) dissolved in dimethyl sulphoxide to block calcitonin gene-related peptide (CGRP) receptor 1; a mix of neurokinin (NK) receptor antagonists (NK1: SR140333B; NK2: SR48968C; NK3: SR142801, all of them $1 \mu \mathrm{M}$ ) for $20 \mathrm{~min}$ (all Sanofi-Aventis, Paris, France) dissolved in dimethyl sulphoxide to block effects of substance P; and the vasoactive intestinal peptide receptor (VPAC) antagonist PG97$269(25 \mu \mathrm{M})$ for 20 min (Phoenix Pharmaceuticals, Burlingame, CA, USA) dissolved in deionized water to block effects of the vasoactive intestinal peptide (VIP). Additionally, nicotine $(100 \mu \mathrm{m}$; Sigma) was applied in some experiments via pressure pulse application for $600 \mathrm{~ms}$ (Buhner et al., 2009).

\section{Immunhistochemistry}

As described previously, outline of ganglia and neurons could be detected during the rise of intracellular $\left[\mathrm{Ca}^{+2}\right]$ accompanied by the increase in Fluo-4AM fluorescence (Michel et al., 2011). Neurons were identified and distinguished from glia cells by their typical appearance (neurons are larger and round shaped, glia are much smaller and typically oval) and by their response to nicotine or electrical stimulation (only neurons respond directly; Michel et al., 2011; Ostertag et al., 2015). A vital staining of MCs immediately after the recordings was achieved by a $60 \mathrm{~min}$ incubation of the tissue with a R-phycoerythrinconjugated mouse anti CD117 (c-kit) antibody (1:200; 104D2 directed against an extracellular epitope, EXBio, Praha, Czech Republic). After staining, the tissue was washed with Krebs buffer for $5 \mathrm{~min}$. Images of the labeled MCs were acquired using a $3 \mathrm{~W}$ green LED (LE TA2A true green $(521 \mathrm{~nm}) 700 \mathrm{~mA}$ (OSRAM GmbH, Munich, Germany) and a filter cube (F46-004 ET filter set, excitation ET 545/25, dichroic 565, emission ET 605/70; AHT Analysentechnik, Tübingen, Germany). The overlay of the Fluo$4 \mathrm{AM}$ and $\mathrm{CD} 117 / \mathrm{C}$-Kit images allowed analyzing responses of individual MCs in the field of view.

CD117/C-Kit positive MCs were clearly distinguishable from interstitial cells of Cajal (ICC) based on their round shape compared to the star- or radial shaped ICC morphology. In some tissues we verified the MC identification using the mouse antiMC tryptase (1:2,000; Chemicon GmbH, Limburg Germany). In all cases we were able to show that MCs were co-labeled by the c-kit and the MC tryptase antibodies. Enteric neurons were selectively labeled using sheep anti PGP 9.5 (1:20,000; The binding site, Birmingham, UK). Secondary antibodies coupled with Cy 3 (Dianova, Hamburg, Germany) or CF640R (Biotium, Fremont, CA, US) were used. The fluorescence was detected by an epifluorescent microscope (BX61 WI, Olympus, Hamburg, Germany).

\section{Data Analysis}

As parameter for cell activation the maximum intracellular $\left[\mathrm{Ca}^{2+}\right]$-increase relative to resting light level $(\% \Delta \mathrm{F} / \mathrm{F})$ was determined for each application. Additionally, the time (s) from application to the peak $\left[\mathrm{Ca}^{+2}\right]_{\mathrm{i}}$ responses and the relative proportion of responding MCs in the field of view using a $\mathrm{x} 20$ objective $\left(0.08 \mathrm{~mm}^{2}\right)$ was determined. As parameter for the overall $\mathrm{MC}$ activation a $\mathrm{MC}$ response index as the product of the peak $\left[\mathrm{Ca}^{+2}\right]_{\mathrm{i}}$ response $(\% \Delta \mathrm{F} / \mathrm{F})$ and the percentage of responding $\mathrm{MCs}$ was calculated.

The maximal $\left[\mathrm{Ca}^{+2}\right]_{\mathrm{i}}$ increase and the percentage of responding neuronal area (taking the area responding to nicotine as $100 \%$ ) per ganglion were multiplied to obtain the $\mathrm{Ca}$ neuroindex. The application of nicotine was used to identify and distinguish neurons from glia cells, and the nicotine responsive cells matched PGP 9.5 immunoreactive neurons (Mueller et al., 2011; Ostertag et al., 2015). Based on staining with an antibody recognizing $\alpha 1, \alpha 3$, and $\alpha 5$ subunits $98 \%$ of human submucous neurons express nicotinic receptors (own unpublished results). Nevertheless, we cannot claim that the nicotine responsive neurons represent all neurons in a given ganglion. In our hands, nicotine is the most reliable tool to selectively activate enteric neurons.

We measured the distances between responding MCs and nerve fibers or responding ganglia using the overlay of the Fluo-4AM and CD117/C-Kit images and the x20 objective. In experiments with EFS induced nerve stimulation we measured the minimum distance between the activated neural structures (nerve fibers or border of responding ganglia) and the center of the responding MCs. This was possible because we could identify all sufficiently dye loaded vital neural structures in the field of view by EFS. This was not possible in the experiments with anti-IgE induced MC stimulation. Here we did not use EFS stimulation to avoid premature mast cell activation and mediator release. We believe that the one distance measured is representative for nerve-MC as well as MC-nerve signaling. Numbers of tissue, ganglia, and MCs are given in sequence without further specification, e.g., a result based on experiments from 4 tissues, 5 ganglia, and 40 MCs is presented as (4/5/40). Data are expressed as the median with the 25th and 75th quartiles given in parenthesis and separated by slash. Statistical tests and graphs were performed using SigmaPlot 12.5 (Systat Software Inc., Erkrath, Germany). All experiments with blockers were done in a paired fashion. Normally distributed data were analyzed by paired $t$-test; not normally distributed data were analyzed by the Wilcoxon signed rank test, the Mann-Whitney Rank Sum Test and the Friedman repeated measures analysis of variance with post-hoc all pairwise multiple comparison by Tukey test. A Bonferroni procedure was applied. Fisher's exact test was used to test whether $\mathrm{MC}\left[\mathrm{Ca}^{2+}\right]_{\mathrm{i}}$ oscillations were linked to disease, localization of surgical specimens or gender. For all tests a $P<0.05$ was considered significant.

\section{RESULTS}

\section{Basal $\left[\mathrm{Ca}^{2+}\right]_{\mathrm{i}}$ Transients in MC}

Basal activity was recorded and analyzed from 165 MCs in 22 tissues. Twenty-eight MCs (17\% of all MCs) in 13 tissues showed spontaneous oscillations in $\left[\mathrm{Ca}^{2+}\right]_{\mathrm{i}}$ with an average frequency of 0.5 per min (0.3/0.7; Figure 1). Their median amplitude was 


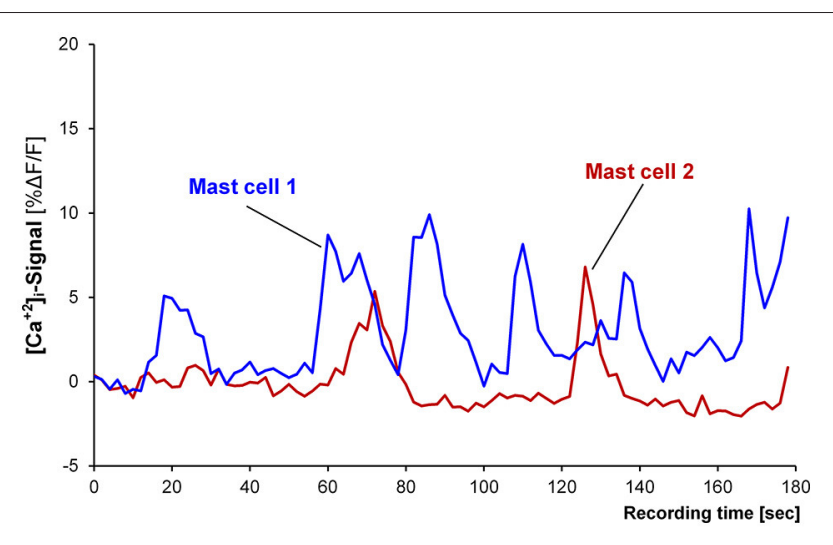

FIGURE 1 | Recording from two spontaneously active mast cells. Mast cell 1 (blue trace) is showing six $\left[\mathrm{Ca}^{2+}\right]_{i}$ peaks and mast cell 2 (red trace) is showing two peaks.

$8.1 \% \Delta \mathrm{F} / \mathrm{F}(5 / 11)$, their median duration about $16 \mathrm{~s}(7 / 25)$. Spontaneous neuronal oscillations in $\left[\mathrm{Ca}^{2+}\right]_{\mathrm{i}}$ were not observed in any of the 22 tissues (23 ganglia). We analyzed 13 tissues with and 9 tissues without oscillating $\left[\mathrm{Ca}^{2+}\right]_{\mathrm{i}}$ transients in MCs. There was no association with age $(67 \pm 11$ vs. $58 \pm 13 ; P=0.053$, $t$-test), gender (female/male: $4 / 9$ vs. $1 / 8 ; P=0.360$ ), intestinal region (small intestine/large intestine: $6 / 7$ vs. $4 / 5 ; P=1.0$ ), or the underlying disease (carcinoma/non-carcinoma: $13 / 0$ vs. $8 / 1 ; P=$ 0.409). For further experiments only those MCs were included, which did not show spontaneous basal activity.

\section{MC to Nerve Signaling}

We selectively stimulated the MCs in close proximity to submucous ganglia by $\operatorname{IgE}$ receptor crosslinking using the monoclonal antibody mAb22E7 $(10 \mu \mathrm{g} / \mathrm{ml})$. The mAb22E7 had no direct effect on neurons. This conclusion was based on the finding that none of the 15 neurons ( 3 tissues and 3 ganglia) which responded to a $1 \mathrm{~s}$ pressure pulse application of nicotine with a Ca-neuroindex of $1186(891 / 1448)$ responded to mAb22E7 application directly onto the ganglia [Ca-neuroindex $0(0 / 0)]$. Additionally, the mAb22E7 application had no effect on sensitivity of the neurons as a second application of nicotine $20 \mathrm{~min}$ later evoked a comparable Ca-neuroindex of 1973 (871/3320). This agreed with our previous study which demonstrated that mAb22E7 did not evoke spike discharge in human submucous neurons (Schemann et al., 2005). In contrast, $63 \%(43 / 75)$ of all MCs in the field of view responded to mAb22E7 application with a strong and long-lasting $\left[\mathrm{Ca}^{2+}\right]_{\mathrm{i}}$ increase (Figure 2; Table 1). In five tissues and $34 \mathrm{MCs}, \mathrm{mAb} 22 \mathrm{E} 7$ was re-applied $20 \mathrm{~min}$ later. The $\mathrm{MC}$ activation was strongly reduced (Figure 2) from $20.4 \% \Delta \mathrm{F} / \mathrm{F}(12.5 / 35.9)$ to $6.1 \% \Delta \mathrm{F} / \mathrm{F}(0.0 / 11.9$; $P=0.002)$. Likewise, the MC response index dropped from $1576(821 / 2521)$ to $366(88 / 735 ; P=0.01)$. $\left[\mathrm{Ca}^{2+}\right]_{\mathrm{i}}$ transients in submucous neurons subsequently to $\mathrm{MC}$ activation with mAb22E7 were observed in 14 out of 35 ganglia, however only in a limited number of neurons (Figure 2). The calculated median percentage of responding neuronal area showing activation (taking nicotine-responsive neurons as 100\%) was therefore
$0 \%\left(0 / 5.9\right.$; Table 1). The maximum of the neuronal $\left[\mathrm{Ca}^{2+}\right]_{\mathrm{i}}$ signal was $6.6 \% \Delta \mathrm{F} / \mathrm{F}$. It occurred $208 \mathrm{~s}$ after the onset of the stimulus and thus clearly later than the maximum MC responses. However, since the neuronal responses were recorded so seldom we decided to forgo further pharmacological characterization of this phenomenon.

To confirm that mAb22E7 is able to cause MC degranulation in our human submucous plexus preparations we incubated the tissues $(n=2)$ with either mAb22E7 $(10 \mu \mathrm{g} / \mathrm{ml})$ or with Krebs buffer (control) for $60 \mathrm{~s}$ and quantified the histamine concentrations in both the supernatants and the tissues. After control incubation the histamine concentration in the supernatants was on average $0.19 \mathrm{ng} / \mathrm{ml}^{*} \mathrm{mg}$. The incubation with $\mathrm{mAb} 22 \mathrm{E} 7$ increased this value to $4.13 \mathrm{ng} / \mathrm{ml}^{*} \mathrm{mg}$. The tissue histamine concentrations were higher, however, they followed a similar patterns (control: $105.1 \mathrm{ng} / \mathrm{ml}^{*} \mathrm{mg}$ vs. $224.4 \mathrm{ng} / \mathrm{ml}^{*} \mathrm{mg}$ after mAb22E7 incubation).

\section{Nerve to MC Signaling}

We selectively stimulated the neurons via EFS which evoked responses instantaneously upon the onset of the stimulus and reached the maximum of $38.4 \% \Delta \mathrm{F} / \mathrm{F}(27.1 / 51.7) 2 \mathrm{~s}(2 / 3)$ after the onset of the stimulus (34 tissues/35 ganglia; Figure 3A). In these tissues a total number of $168 \mathrm{MCs}$ were identified by IHC staining. Thirty-three percent $(22 / 66)$ of them showed a $\left[\mathrm{Ca}^{2+}\right]_{\mathrm{i}}$ signal following the electrical nerve stimulation. The $\left[\mathrm{Ca}^{2+}\right]_{\text {i }}$ peak of $8.0 \% \Delta \mathrm{F} / \mathrm{F}(4.3 / 14.8)$ was reached later than the neuronal peak maximum, i.e., $11 \mathrm{~s}(7 / 25)$ after the onset stimulus. The MC response lasted 19s (15/31; Figure 3A). The minimum distances between the EFS activated nerve fibers or ganglia and the responding MCs were $5 \mu \mathrm{m}(1 / 12)$ or 32 (11/53), respectively.

EFS evoked nerve and MC responses were reproducible (Figure 3A). In $57 \%$ of the tissues MCs showed similar $\left[\mathrm{Ca}^{2+}\right]_{\mathrm{i}}$ transients after two EFS $20 \mathrm{~min}$ apart. Parameters for the MC responses were exemplarily calculated for $78 \mathrm{MCs}$ in 13 tissues (Figures 3B-D). Neither the peak amplitude nor the time point of the maximum $\left[\mathrm{Ca}^{2+}\right]_{\mathrm{i}}$ signal or the percentage of responding MCs differed significantly between two EFS. For further pharmacological studies, only tissues with reproducible MC activation were used.

TTX $(1 \mu \mathrm{M})$ blocked the EFS evoked nerve as well as the $\mathrm{MC}$ activation which both recovered after $60 \mathrm{~min}$ washout period (Figures 4A,B). Importantly, TTX had no direct effect on MC activation by mAb22E7. After $20 \mathrm{~min}$ perfusion with TTX, mAb22E7 application activated $88 \%$ of the MCs in the field of view with a median maximum $\left[\mathrm{Ca}^{2+}\right]_{\mathrm{i}}$ signal of $33.7 \% \Delta \mathrm{F} / \mathrm{F}$ $(23.9 / 44.1 ; 2 / 2 / 25)$. These values were comparable to mAb22E7 effects without TTX (see Table 1).

Next, we investigated which neurotransmitters were involved in the nerve-MC signaling. We focused on the most likely candidates CGRP, SP and VIP (see section Introduction). We repeated the EFS in the presence of the CGRP receptor antagonist BIBN-4096 (10 $\mu \mathrm{M}$; Doods et al., 2000) and analyzed MC activation by calculating the MC response index. BIBN-4096 strongly reduced the MC responses (Figure 5). In contrast, blocking SP effects using a mixture of NK1, NK2, and NK3 receptor antagonists (all $1 \mu \mathrm{M}$ ) did not significantly reduce 
A

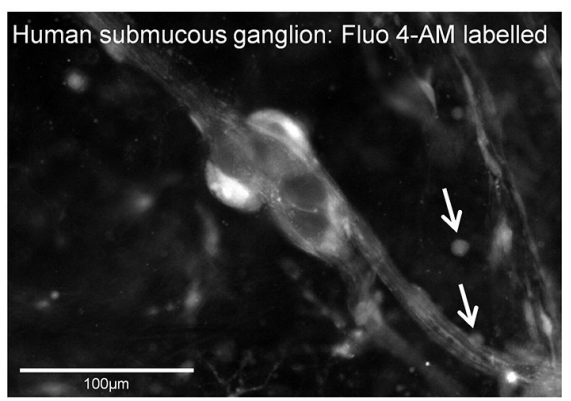

B

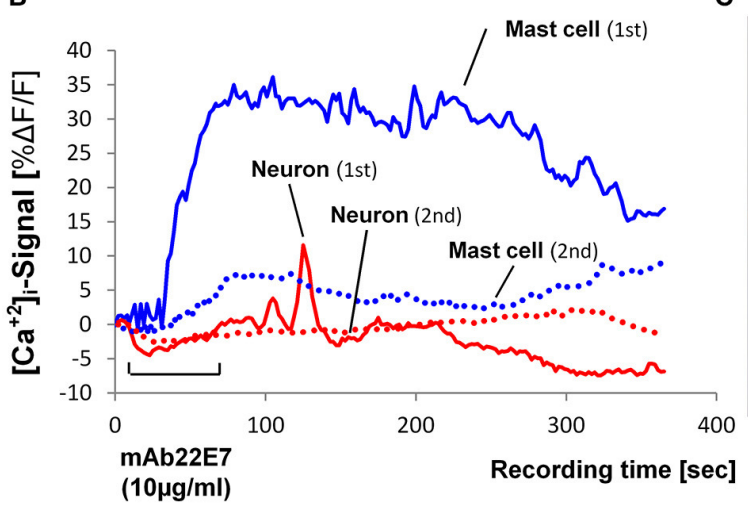

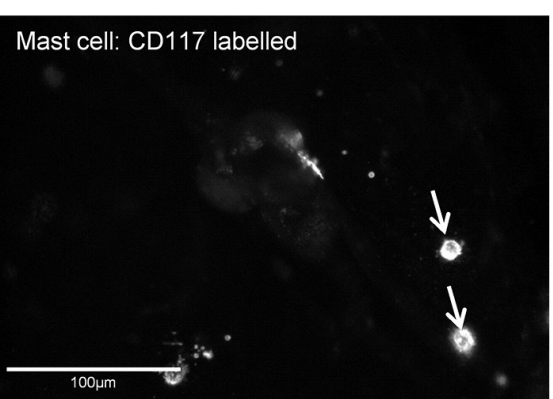

C

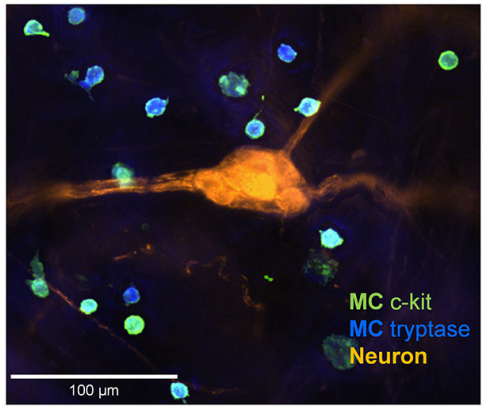

FIGURE 2 | (A) Image on the left panel shows a human submucous ganglion stained with the Ca ${ }^{2+}$ sensitive dye Fluo-4AM. The arrows point toward two MCs which were identified by R-phycoerythrin-conjugated mouse anti CD117 (c-kit) labeling shown in the right panel. (B). Traces of [Ca $\left.{ }^{2+}\right]_{i}$ transients in a mast cell (blue trace) and a submucous neuronal cell body (red trace) in response to mast cell activation by FceRl receptor crosslinking by mAb22E7 micro-pefusion (10 $\mu \mathrm{g} / \mathrm{ml}$ for $60 \mathrm{~s}$ ). The mast cell showed a strong, long-lasting increase of $\left[\mathrm{Ca}^{2+}\right]_{i}(1 \mathrm{st} \mathrm{mAb} 22 \mathrm{E} 7)$. This response was strongly reduced after a second mAb22E7 application (see dotted line). Also, the response of the submucous neuron (solid line shows the signal after the first mAb22E7 application) is greatly reduced after the mAb22E7 application of (see dotted line). Panel (C) demonstrate a 100\% overlap between anti-MC tryptase (blue) anti CD117 (green) MC staining. Enteric neurons were labeled with anti-PGP 9.5 (orange).

TABLE 1 | Mast cell and neuronal responses to mast cell activation by lgE receptor cross linking with $\mathrm{mAb} 22 \mathrm{E} 7$.

\begin{tabular}{lcc}
\hline & Mast Cells $^{a}$ & Nerve cell bodies \\
\hline Peak amplitude $\left[\mathrm{Ca}^{+2}\right]_{\mathrm{i}} \% \Delta \mathrm{F} / \mathrm{F}$ & $19.5(11.2 / 38.8)$ & $6.6(5.1 / 11.6)$ \\
Time of peak $\left[\mathrm{Ca}^{+2}\right]_{\mathrm{i}}[\mathrm{s}]$ & $90.0(63.5 / 144.0)$ & $208.0(83.8 / 258.8)$ \\
Responding cells $[\%]$ & $63(43 / 75)$ & $0(0 / 5.9)$ \\
Response Index $[\% \Delta \mathrm{F} / \mathrm{F} \times \%$ & $1,542(800 / 2,429)$ & $0(0 / 36)$ \\
responding cells] & & \\
\hline
\end{tabular}

${ }^{a}$ All values are medians with 25 and $75 \%$ quartiles in parenthesis and based on 29 tissues, 35 ganglia, and 223 mast cells.

the MC activation (Figure 5). Furthermore, the VPAC receptor antagonist $(25 \mu \mathrm{M}, 20 \mathrm{~min})$ significantly reduced the EFS evoked MC activation (Figure 5). In summary, the results of the pharmacological experiments indicate that CGRP and VIP rather than NK receptor meditated SP played a role in nerve mediated $\mathrm{MC}$ activation in human submucous plexus.

\section{DISCUSSION}

This is the first study to demonstrate nerve-MC signaling at a cellular level in intact intestinal tissue. We used $\left[\mathrm{Ca}^{+2}\right]_{\mathrm{i}}$ imaging in human submucous plexus to synchronously record MC and nerve activity after selective stimulation of nerves and mast cells. We presented strong evidence that MCs were activated by nerves based on the finding that the nerve blocker TTX abolished $\left[\mathrm{Ca}^{+2}\right]_{\mathrm{i}}$ signals in neurons and MCs. We ruled out TTX effects on mast cells because mAb22E7 induced activation of MCs was not TTX sensitive. This agreed with studies showing the lack of functional expression of voltage and TTX sensitive sodium channels in MCs (Bradding et al., 2003). The nerveMC signaling involved the neuropeptides CGRP and VIP rather than SP acting through NK receptors. Nerve activation upon specific stimulation of MCs via IgE receptor cross-linking was also recorded, however to a much lesser extent. All in all, results suggested nerve to $\mathrm{MC}$ as well as MC to nerve communication.

Compound $48 / 80$ was widely used to promote MC degranulation and to study $\mathrm{MC}$ to nerve communication (Janiszewski et al., 1994; De Jonge et al., 2004; Rychter et al., 2011; Wang et al., 2014; Bell et al., 2015). In a previous study, however, we revealed a direct and strong excitatory action of compound $48 / 80$ on enteric neurons and visceral afferents (Schemann et al., 2012). Therefore, functional changes measured in tissue or animal models may be confounded by neural effects of compound 48/80. Classical MC activation in tissues occurred 


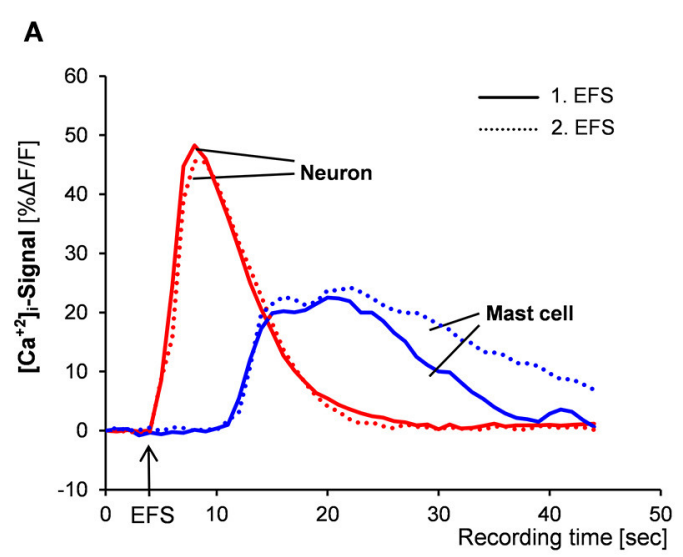

C

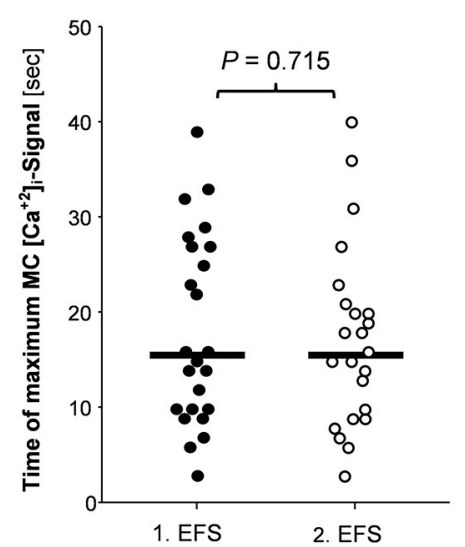

B

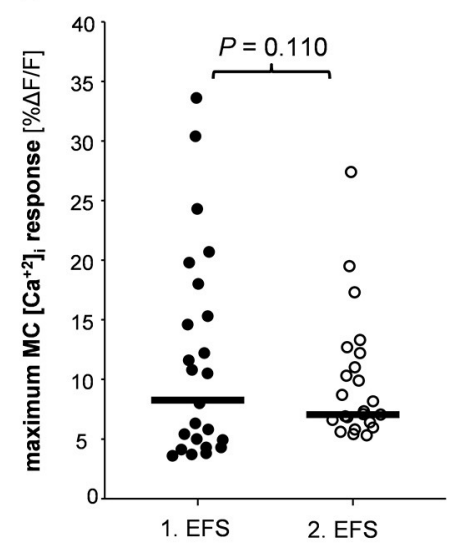

D

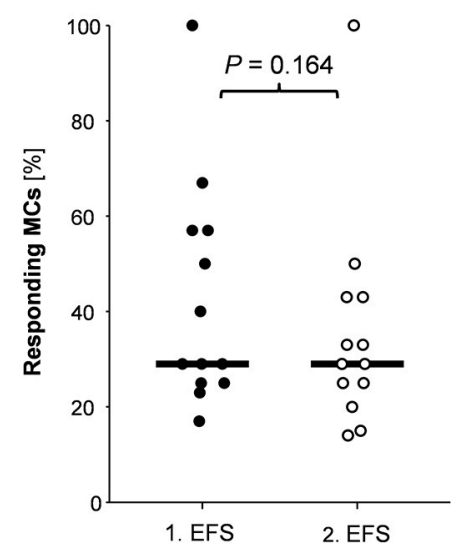

FIGURE 3 | (A) Traces of $\left[\mathrm{Ca}^{2+}\right]_{i}$ transients of a neuron (red trace) and a mast cell (blue trace) in response to nerve stimulation (EFS). Neuronal responses occurred instantaneously with the stimulus, while MC activation occurred after a time delay. Both, neuronal responses and mast cell activation were reproducible (compare solid and dotted traces). There were no differences between 1st and 2 nd EFS evoked MC signaling regarding amplitude of $\left[\mathrm{Ca}^{2+}\right]_{i}$ peaks (B), time point of the $\left[\mathrm{Ca}^{2+}\right]_{i}$ peak (C) or percentage of responding mast cells (D). P-values based on Wilcoxon Signed Rank Test. Results based on 13 tissues, 13 ganglia, and 78 mast cells.

through cross-linking of adjacent high affinity receptors for the Fce portion of IgE (FceRI) on the MC surface by a multivalent IgE-antigen. Receptor cross-linking was induced by the antibody mAb22E7 that has been previously used to activate human intestinal mast cells (Bischoff et al., 1999; Sellge et al., 2005). We used it at $10 \mu \mathrm{g} / \mathrm{ml}$ which corresponded to results that mAb22E7 evoked a maximum histamine release at $2.5-10 \mu \mathrm{g} / \mathrm{ml}$ (Riske et al., 1991). This suggested that we used sufficiently high mAb22E7 concentrations. We verified MC mediator release in our tissues by showing that histamine release increased by more than 20-fold during brief exposure to mAb22E7. Additionally, mAb22E7 was specific for MCs as activation of other cells, in particular neurons, was not observed in our human submucous preparations.

In the present study around $63-88 \%$ of all MCs in the field of view showed a strong and long lasting $\left[\mathrm{Ca}^{+2}\right]_{\mathrm{i}}$ increase after mAb22E7 stimulation. The failure to activate all MCs may be due to insufficient dye loading or non-viable MCs. In addition, to avoid spill-over to adjacent areas, we adjusted the microperfusion system such that not the entire field of view was exposed to the drug solution. The $\mathrm{MC}\left[\mathrm{Ca}^{+2}\right]_{\mathrm{i}}$ response closely resembled the signaling pattern which has been related to MC degranulation (Rychter et al., 2011; Wang et al., 2014; Gaudenzio et al., 2016). Strikingly, neural activation in terms of $\left[\mathrm{Ca}^{+2}\right]_{i}$ transients, was rarely observed and if present of small amplitude. The activation was clearly triggered as the neuronal signal always occurred after MC responses. Nonetheless, we could not provide experimental proof as the neural response after MC stimulation was too rare and moreover not reproducible.

The delay in $\left[\mathrm{Ca}^{+2}\right]_{\mathrm{i}}$ transients between $\mathrm{MC}$ and enteric neurons was around $100 \mathrm{~s}$. There are a number of factors influencing the timing of responses between MCs and nerves. This includes delays between $\left[\mathrm{Ca}^{+2}\right]_{\mathrm{i}}$ peak and release of MC mediators, diffusion of mediators to the neuronal target, activation of G-protein coupled receptors (GPCRs) and GPCR induced enhanced $\left[\mathrm{Ca}^{+2}\right]_{\mathrm{i}}$ signal. Single cell measurements in cultured mast cell lines found a 30-60 s delay between the $\left[\mathrm{Ca}^{+2}\right]_{\mathrm{i}}$ increase and secretion of mediators (Kim et al., 1997). The first 


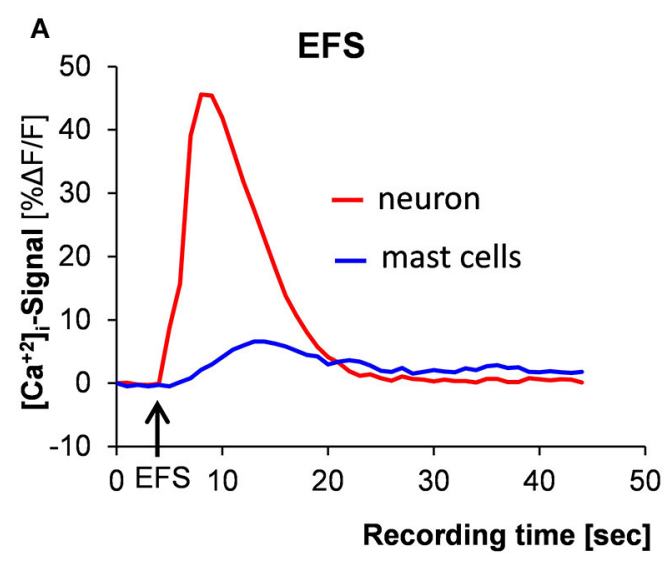

B
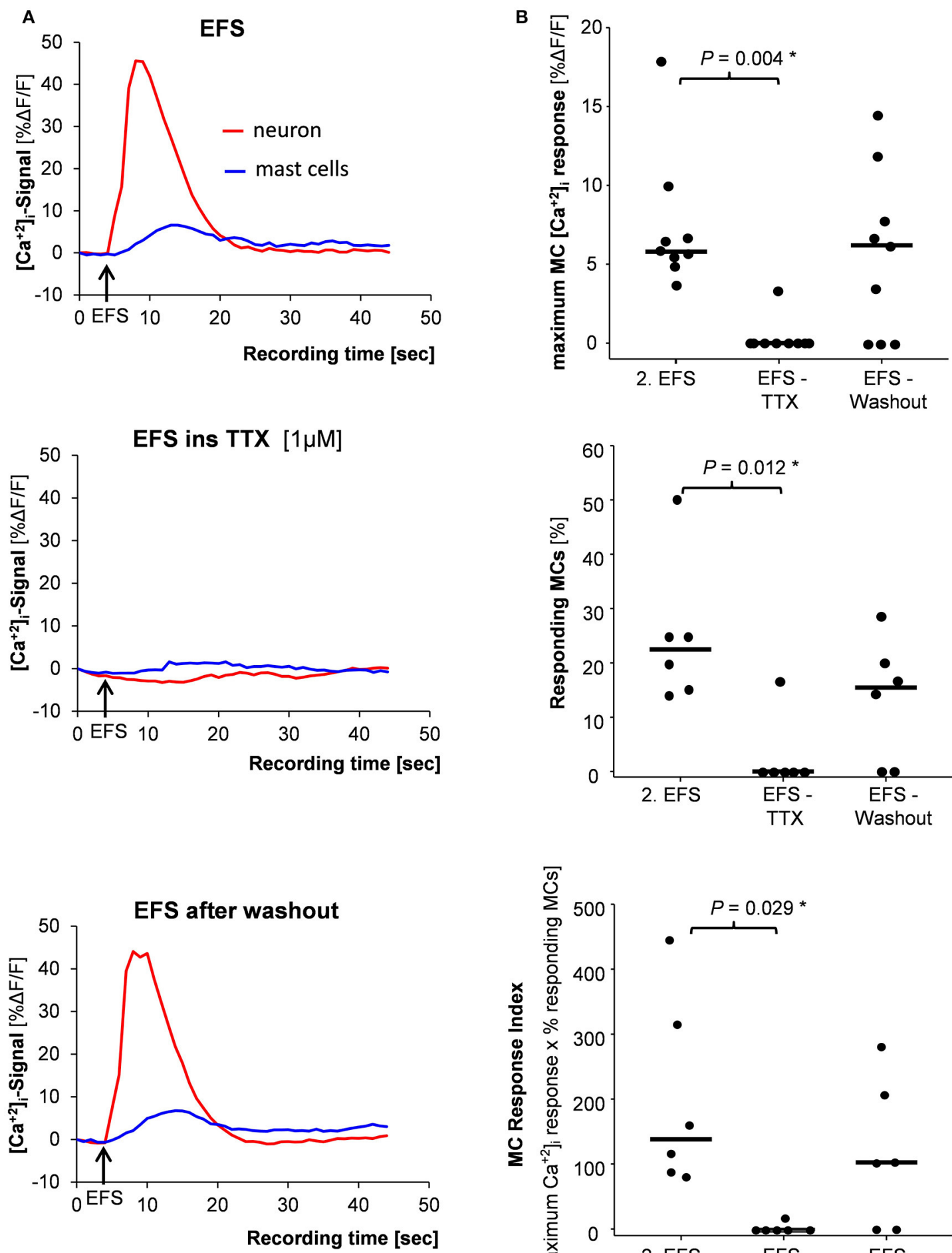
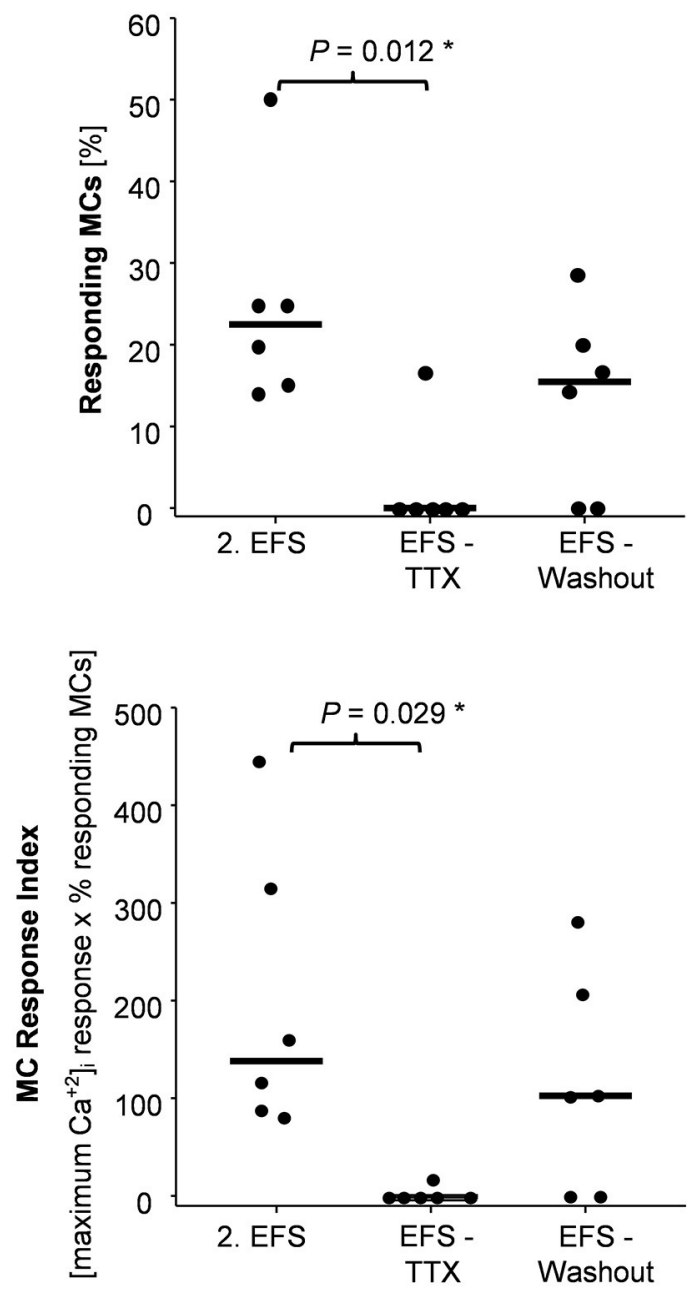

FIGURE 4 | (A) Mast cell activation (blue trace) evoked by nerve stimulation (EFS) (red trace) was completely blocked by the nerve blocker tetrododoxin (TTX) (middle panel) and returned after TTX washout (lower panel). (B) Correspondingly, the amplitude of the $\left[\mathrm{Ca}^{2+}\right]_{i}$ signal (upper panel), the percentage of responding mast cells (middle panel) and the mast cell response index (lower panel) were significantly reduced by TTX. $P$-values based on Friedman analysis of variance on ranks and post-hoc Tukey test; results based on 6 tissues, 6 ganglia, and 39 mast cells. 

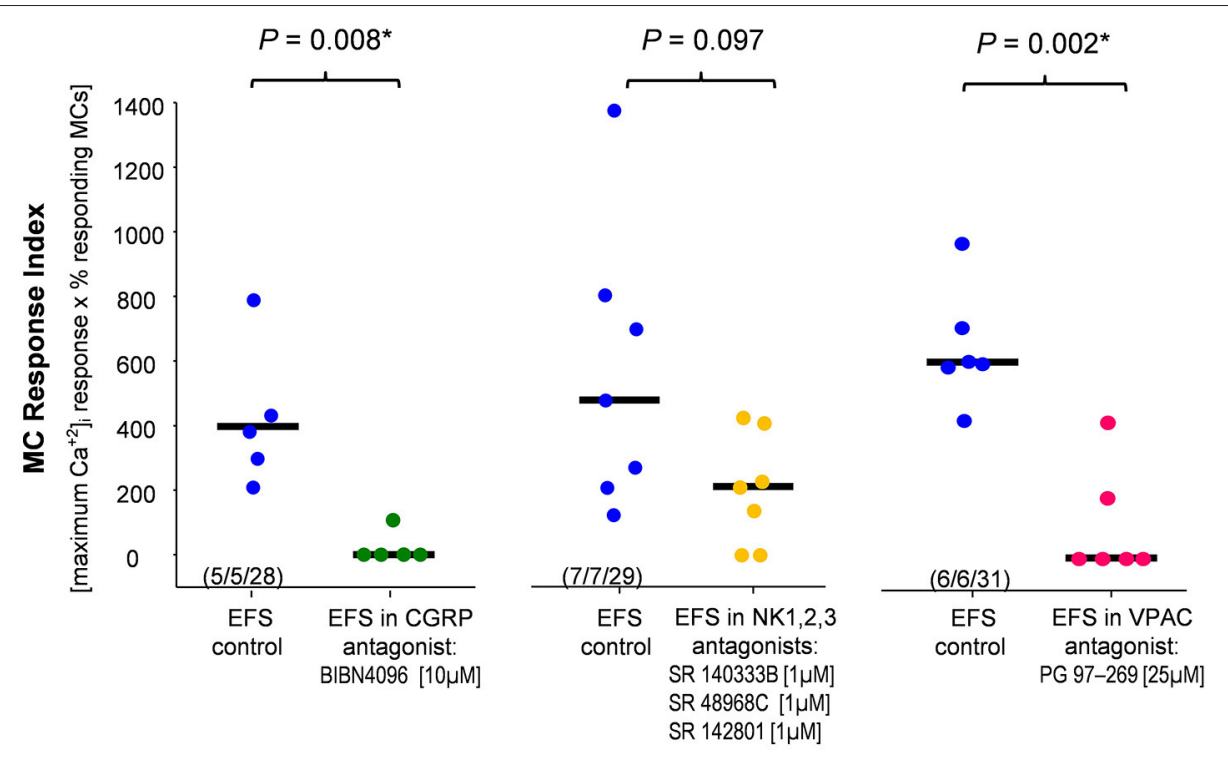

FIGURE 5 | Calcitonin gene-related peptide (CGRP), vasoactive intestinal peptide (VIP) but not substance P contributed to nerve evoked mast cell activation. The CGRP antagonist and the VIP antagonist significantly reduced the EFS evoked mast cell response index. Co-application of neurokinin receptor antagonists had no significant effect. P-values based on Mann-Whitney Rank Sum Test; (tissues, ganglia, mast cells).

spike after application of histamine onto human submucous neurons is discharged after 1-2s (Breunig et al., 2007). The $\left[\mathrm{Ca}^{+2}\right]_{\mathrm{i}}$ peak in response to enhanced spike discharge occurred much later. This is the reason that we observed delays of about $20 \mathrm{~s}$ between application of PAR agonists (among them tryptase) and the peak $\left[\mathrm{Ca}^{+2}\right]_{\mathrm{i}}$ response in human submucous neurons (Mueller et al., 2011; Ostertag et al., 2017). There was a delay of several minutes between $\left[\mathrm{Ca}^{+2}\right]_{\mathrm{i}}$ increase and degranulation (Gaudenzio et al., 2016). Last but not least, there is an unknown time needed for diffusion of MC mediators to their receptors on enteric neurons. Therefore, our average delay of around $100 \mathrm{~s}$ are somehow expected and within the range suggested by the above referenced studies.

Previously, we demonstrated that a "mast cell mediator cocktail," which was released from isolated human intestinal mast cells by IgE receptor cross linking (Schemann et al., 2005) as well as single MC degranulation products like histamine (Breunig et al., 2007) and proteases (Mueller et al., 2011) evoked strong and immediate action potential discharge in human and guinea pig submucous neurons. Thus, the question remained why the neuronal response after MC stimulation in the present study was observed so sporadically. One possible explanation is that mediator release from a limited number of nerve-associated MCs may be not sufficient to activate neurons nearby. Neuronal cell bodies were on average $32 \mu \mathrm{m}$ away from the activated mast cell. Although, volume transmission may happen over even much larger distances (Zoli et al., 1999), another scenario is at least as plausible. The signaling of MCs to nerves likely occurred at the neurites and activation of the nerve cell bodies may be a consequence of an activation of such extra-ganglionic processes. Signaling between MCs and neurites may not necessarily activate a neuronal cell body in the ganglion-nearby MCs but in more distant ganglia outside our recording area. With the limited amount of mAb22E7 it was not possible to perfuse the entire tissue to test this hypothesis. Based on the following finding, the above discussed methodological limitations cannot fully explain the rare occurrence of MC to nerve signaling. Although, the transmural stimulation of all nerves evoked a strong MC activation we never observed a late onset $\left[\mathrm{Ca}^{+2}\right]_{\mathrm{i}}$ signal in nerves. This would be expected if release of MC mediators feedback on nerve activity. Weighing all the above discussed arguments, we conclude that an MC to nerve signaling is a rather rare event in our samples of macroscopically normal tissue. Having said that, a $\mathrm{MC}$ to nerve signaling may be more prominent in disease states like IBS or IBD where the number and/or the reactivity of MCs in close proximity to nerves is increased (Raithel et al., 2001; Barbara et al., 2004, 2007; Cenac et al., 2007; Guilarte et al., 2007).

Nerve to MC signaling was frequently observed and occurred in 33\% of MCs. The transmural EFS used in the present study was stimulating the entire preparation and thus activated all submucous as well as extrinsic nerves. In the present study we calculated a median distance of $5 \mu \mathrm{m}$ between activated nerve fibers and MCs. The spatial resolution of the imaging set up did not allow in tissue recordings from single axons to follow the spread of action potentials from the cell body along the axon to the varicose endings at the transmission to MCs. The present study provided direct evidence that nerves activated MCs in intestinal preparations. This conclusion was supported by the finding that the $\left[\mathrm{Ca}^{2+}\right]_{\mathrm{i}}$ signals in MCs were completely blocked by TTX. The mediators involved were CGRP and VIP rather than SP. In human colonic submucous plexus CGRP is exclusively expressed by extrinsic, very likely sensory, nerve fibers with intraganglionic terminals as well as varicose endings outside ganglia (Schneider et al., 2001). MCs in the human intestine 
express CGRP receptors (Wang et al., 2014). A major result of the present study was that blocking these receptors with the selective and high-affinity antagonist BIBN-4096, strongly reduces the MC activation upon nerve stimulation. This clearly stressed the role of CGRP in nerve mediated activation of MCs in intact human submucous plexus. These findings are in accordance with the results in cell cultures (De Jonge et al., 2004; Rychter et al., 2011) and rodent plexus preparations (Wang et al., 2014). VIP was also involved in the nerve mediated MC activation. The VPAC receptor antagonist PG97-269 (Gourlet et al., 1997) reduced nerve evoked MC activation. According to binding studies, the affinity of PG97-269 is higher to VPAC1, however it binds and inhibits VPAC2 actions as well (Gourlet et al., 1997). VIP is a prominent neuropeptide, produced by neurons in human submucous plexus (Schneider et al., 2001). Functions are ranging from neurotransmission to immunomodulation (Said and Rosenberg, 1976), the latter was reflected by the ability of VIP to induce degranulation of rat brain MCs (Tunçel et al., 2005). The vast majority of VIP positive structures in human intestinal preparations originated in the enteric nervous system. VIP positive cell bodies have not been found in dorsal root ganglia of human fetus or newborn infants (Charnay et al., 1985). We therefore believe that an earlier study suggesting that VIP is a sensory transmitter rather described a capsaicin evoked release of CGRP which then activated VIP release from enteric neurons (Maggi et al., 1989). We have no final explanation for the finding that the CGRP as well as the VIP antagonist almost abolished the $\mathrm{MC}$ response to EFS. One reason, though speculative, may be that both act in such a synergistic way that blocking the action of one is also abolishing the response to the other mediator or inhibiting it to such an extent that we cannot resolve the response anymore. We have no evidence for any unspecific effects of the blockers and we applied the protocols and the concentrations also used by others (BIBN4096: (De Jonge et al., 2004; Rychter et al., 2011); VPAC antagonist: (Krueger et al., 2016).

Surprisingly, we found no evidence that SP was involved in $\mathrm{MC}$ activation. However, we have to acknowledge that the effects of the neurokinin receptor antagonists barely missed significance. It seems that some MCs responded nicely other not at all to blockade of SP action. This agrees with the finding that only up to $17 \%$ of mast cells in human intestine express NK1 receptors (Wang et al., 2014). Substance P is only present in a small proportion of human submucous neurons and is, unlike in rodent intestine, very rarely co-localized with extrinsic CGRP positive fibers (Ekblad et al., 1989; Schneider et al., 2001). There is abundant evidence in rodent models that SP activated MCs (Janiszewski et al., 1994; Wang et al., 2014; Gaudenzio et al., 2016) and induced degranulation (Suzuki et al., 2001; Kulka et al., 2008). However, the presence of tachykinin receptors on mammalian MCs remained controversial (Lecci et al., 2006). Bischoff et al. (2004) showed that cultured human intestinal MCs do not constitutively express NK receptors, however, when primed by stem cell factor or interleukin-4, they started to express NK1 receptors and responded to high concentrations of SP with degranulation. Thus, NK receptor mediated SP effects on MCs may vary with their precondition.

We observed in few cases oscillations in $\left[\mathrm{Ca}^{+2}\right]_{\mathrm{i}}$ signals of MCs. Resting $\left[\mathrm{Ca}^{+2}\right]_{\mathrm{i}}$ fluctuation commonly occurred in MCs and was suggested to represent fluctuations in the filling state of internal $\mathrm{Ca}^{2+}$ stores (Millard et al., 1989; Narenjkar et al., 1999).

This is the first study to demonstrate nerve-MC interaction on a cellular level in intact human submucous plexus imaging $\left[\mathrm{Ca}^{+2}\right]_{\mathrm{i}}$ transients. According to these results we propose a functional nerve mast cell axis in the human gut. A nerve to mast cell signaling was more prominent than a mast cell to nerve signaling.

\section{ETHICS STATEMENT}

This study involved in vitro experiments on surgical waste tissue from human intestine. This study was carried out in accordance with the recommendations of the ethics committee of the Technical University of Munich with written informed consent from all subjects. All subjects gave written informed consent in accordance with the Declaration of Helsinki. The protocol was approved by the ethics committee of the Technical University of Munich (project approval 5242/11).

\section{AUTHOR CONTRIBUTIONS}

SB: designed the study and performed the experiments as well as analysis and interpretation of data. She drafted the manuscript, approved the final version, and is accountable for all aspects of the work. NB: performed experiments as well as analysis and interpretation of data. She critically revised the manuscript. She is accountable for all aspects of the work. WG: performed experiments as well as analysis and interpretation of data. $\mathrm{He}$ critically revised the manuscript, approved it for publication and is accountable for all aspects of the work. PG: performed the histamine analysis. He critically revised the manuscript, approved it for publication and is accountable for all aspects of the work. ID, GC, and FZ: made the work possible by providing human samples and medical council. They critically revised the manuscript and approved it for publication. They are accountable for correct patient characterization and material handling. HD: She critically reviewed the manuscript for important intellectual content, approved it for publication and is accountable for all aspects of the work. MS: formed the concept and designed the study as well as made the work possible by obtaining funding. He critically reviewed the manuscript for important intellectual content, gave final approval for publication and is accountable for all aspects of the work.

\section{ACKNOWLEDGMENTS}

This work was supported by DFG SPP 1394 and the Technische Universität München within the funding program Open Access Publishing. 


\section{REFERENCES}

Barbara, G., Stanghellini, V., De Giorgio, R., Cremon, C., Cottrell, G. S., Santini, D., et al. (2004). Activated mast cells in proximity to colonic nerves correlate with abdominal pain in irritable bowel syndrome. Gastroenterology 126, 693-702. doi: 10.1053/j.gastro.2003.11.055

Barbara, G., Wang, B., Stanghellini, V., de Giorgio, R., Cremon, C., Di Nardo, G., et al. (2007). Mast cell-dependent excitation of visceral-nociceptive sensory neurons in irritable bowel syndrome. Gastroenterology 132, 26-37. doi: 10.1053/j.gastro.2006.11.039

Bell, A., Althaus, M., and Diener, M. (2015). Communication between mast cells and rat submucosal neurons. Pflugers Arch. 467, 1809-1823. doi: 10.1007/s00424-014-1609-9

Bischoff, S. C. (2007). Role of mast cells in allergic and non-allergic immune responses: comparison of human and murine data. Nat. Rev. Immunol. 7, 93-104. doi: 10.1038/nri2018

Bischoff, S. C., Mayer, J. H., and Manns, M. P. (2000). Allergy and the gut. Int. Arch. Allergy Immunol. 121, 270-283. doi: 10.1159/000024340

Bischoff, S. C., Schwengberg, S., Lorentz, A., Manns, M. P., Bektas, H., Sann, H., et al. (2004). Substance P and other neuropeptides do not induce mediator release in isolated human intestinal mast cells. Neurogastroenterol. Motil. 16, 185-193. doi: 10.1111/j.1365-2982.2004.00502.x

Bischoff, S. C., Sellge, G., Lorentz, A., Sebald, W., Raab, R., and Manns, M. P. (1999). IL-4 enhances proliferation and mediator release in mature human mast cells. Proc. Natl. Acad. Sci. U.S.A. 96, 8080-8085. doi: 10.1073/pnas. 96.14 .8080

Bischoff, S. C., Wedemeyer, J., Herrmann, A., Meier, P. N., Trautwein, C., Cetin, Y., et al. (1996). Quantitative assessment of intestinal eosinophils and mast cells in inflammatory bowel disease. Histopathology 28, 1-13. doi: 10.1046/j.1365-2559.1996.262309.x

Bradding, P., Okayama, Y., Kambe, N., and Saito, H. (2003). Ion channel gene expression in human lung, skin, and cord blood-derived mast cells. J. Leukoc. Biol. 73, 614-620. doi: 10.1189/jlb.1202602

Breunig, E., Michel, K., Zeller, F., Seidl, S., Weyhern, C. W., and Schemann, M. (2007). Histamine excites neurones in the human submucous plexus through activation of $\mathrm{H} 1, \mathrm{H} 2, \mathrm{H} 3$ and $\mathrm{H} 4$ receptors. J. Physiol. 583, 731-742. doi: 10.1113/jphysiol.2007.139352

Buhner, S., Li, Q., Vignali, S., Barbara, G., De Giorgio, R., Stanghellini, V., et al. (2009). Activation of human enteric neurons by supernatants of colonic biopsy specimens from patients with irritable bowel syndrome. Gastroenterology 137, 1425-1434. doi: 10.1053/j.gastro.2009.07.005

Buhner, S., and Schemann, M. (2012). Mast cell-nerve axis with a focus on the human gut. Biochim. Biophys. Acta 1822, 85-92. doi: 10.1016/j.bbadis.2011.06.004

Cenac, N., Andrews, C. N., Holzhausen, M., Chapman, K., Cottrell, G., AndradeGordon, P., et al. (2007). Role for protease activity in visceral pain in irritable bowel syndrome. J. Clin. Invest. 117, 636-647. doi: 10.1172/JCI29255

Charnay, Y., Chayvialle, J. A., Said, S. I., and Dubois, P. M. (1985). Localization of vasoactive intestinal peptide immunoreactivity in human foetus and newborn infant spinal cord. Neuroscience 14, 195-205. doi: 10.1016/0306-4522(85)90173-3

De Jonge, F., De Laet, A., Van Nassauw, L., Brown, J. K., Miller, H. R. P., van Bogaert, P.-P., et al. (2004). In vitro activation of murine DRG neurons by CGRP-mediated mucosal mast cell degranulation. Am. J. Physiol. Gastrointest. Liver Physiol. 287, G178-191. doi: 10.1152/ajpgi.00528.2003

Doods, H., Hallermayer, G., Wu, D., Entzeroth, M., Rudolf, K., Engel, W., et al. (2000). Pharmacological profile of BIBN4096BS, the first selective small molecule CGRP antagonist. Br. J. Pharmacol. 129, 420-423. doi: 10.1038/sj.bjp.0703110

Dvorak, A. M., McLeod, R. S., Onderdonk, A. B., Monahan-Earley, R. A., Cullen, J. B., Antonioli, D. A., et al. (1992). Human gut mucosal mast cells: ultrastructural observations and anatomic variation in mast cell-nerve associations in vivo. Int. Arch. Allergy Immunol. 98, 158-168. doi: 10.1159/000236180

Dvorak, A. M., Monahan, R. A., Osage, J. E., and Dickersin, G. R. (1978). Mast-cell degranulation in Crohn's disease. Lancet Lond. Engl. 311:498. doi: 10.1016/S0140-6736(78)90155-1

Ekblad, E., Arnbjörnsson, E., Ekman, R., Håkanson, R., and Sundler, F. (1989). Neuropeptides in the human appendix. Distribution and motor effects. Dig. Dis. Sci. 34, 1217-1230. doi: 10.1007/BF01537270
Frieling, T., Cooke, H. J., and Wood, J. D. (1994). Neuroimmune communication in the submucous plexus of guinea pig colon after sensitization to milk antigen. Am. J. Physiol. 267, G1087-G1093.

Furuno, T., Ma, D., van der Kleij, H. P. M., Nakanishi, M., and Bienenstock, J. (2004). Bone marrow-derived mast cells in mice respond in co-culture to scorpion venom activation of superior cervical ganglion neurites according to level of expression of NK-1 receptors. Neurosci. Lett. 372, 185-189. doi: 10.1016/j.neulet.2004.08.008

Gaudenzio, N., Sibilano, R., Marichal, T., Starkl, P., Reber, L. L., Cenac, N., et al. (2016). Different activation signals induce distinct mast cell degranulation strategies. J. Clin. Invest. 126, 3981-3998. doi: 10.1172/JCI85538

Gourlet, P., De Neef, P., Cnudde, J., Waelbroeck, M., and Robberecht, P. (1997). In vitro properties of a high affinity selective antagonist of the VIP1 receptor. Peptides 18, 1555-1560. doi: 10.1016/S0196-9781(97)00230-1

Guilarte, M., Santos, J., de Torres, I., Alonso, C., Vicario, M., Ramos, L., et al. (2007). Diarrhoea-predominant IBS patients show mast cell activation and hyperplasia in the jejunum. Gut 56, 203-209. doi: 10.1136/gut.2006.100594

Janiszewski, J., Bienenstock, J., and Blennerhassett, M. G. (1994). Picomolar doses of substance $\mathrm{P}$ trigger electrical responses in mast cells without degranulation. Am. J. Physiol. 267, C138-C145.

Kim, T. D., Eddlestone, G. T., Mahmoud, S. F., Kuchtey, J., and Fewtrell, C. (1997). Correlating $\mathrm{Ca} 2+$ responses and secretion in individual RBL-2H3 mucosal mast cells. J. Biol. Chem. 272, 31225-31229. doi: 10.1074/jbc.272.50.31225

Krueger, D., Michel, K., Zeller, F., Demir, I. E., Ceyhan, G. O., Slotta-Huspenina, J., et al. (2016). Neural influences on human intestinal epithelium in vitro. J. Physiol. 594, 357-372. doi: 10.1113/JP271493

Kulka, M., Sheen, C. H., Tancowny, B. P., Grammer, L. C., and Schleimer, R. P. (2008). Neuropeptides activate human mast cell degranulation and chemokine production. Immunology 123, 398-410. doi: 10.1111/j.1365-2567.2007.02705.x

Lecci, A., Capriati, A., Altamura, M., and Maggi, C. A. (2006). Tachykinins and tachykinin receptors in the gut, with special reference to NK2 receptors in human. Auton. Neurosci. Basic Clin. 126-127, 232-249. doi: 10.1016/j.autneu.2006.02.014

Maggi, C. A., Santicioli, P., Del Bianco, E., Geppetti, P., Barbanti, G., Turini, D., et al. (1989). Release of VIP- but not CGRP-like immunoreactivity by capsaicin from the human isolated small intestine. Neurosci. Lett. 98, 317-320. doi: 10.1016/0304-3940(89)90421-7

Margolis, K. G., Gershon, M. D., and Bogunovic, M. (2016). Cellular organization of neuroimmune interactions in the gastrointestinal tract. Trends Immunol. 37, 487-501. doi: 10.1016/j.it.2016.05.003

Michel, K., Michaelis, M., Mazzuoli, G., Mueller, K., Vanden Berghe, P., and Schemann, M. (2011). Fast calcium and voltage-sensitive dye imaging in enteric neurones reveal calcium peaks associated with single action potential discharge. J. Physiol. 589, 5941-5947. doi: 10.1113/jphysiol.2011.219550

Millard, P. J., Ryan, T. A., Webb, W. W., and Fewtrell, C. (1989). Immunoglobulin E receptor cross-linking induces oscillations in intracellular free ionized calcium in individual tumor mast cells. J. Biol. Chem. 264, 19730-19739.

Mueller, K., Michel, K., Krueger, D., Demir, I. E., Ceyhan, G. O., Zeller, F., et al. (2011). Activity of protease-activated receptors in the human submucous plexus. Gastroenterology 141, 2088.e1-2097.e1. doi: 10.1053/j.gastro.2011.08.034

Narenjkar, J., Marsh, S. J., and Assem, E. S. (1999). The characterization and quantification of antigen-induced $\mathrm{Ca} 2+$ oscillations in a rat basophilic leukaemia cell line (RBL-2H3). Cell Calcium 26, 261-269. doi: 10.1054/ceca.1999.0065

Nemethova, A., Michel, K., Gomez-Pinilla, P. J., Boeckxstaens, G. E., and Schemann, M. (2013). Nicotine attenuates activation of tissue resident macrophages in the mouse stomach through the $\beta 2$ nicotinic acetylcholine receptor. PLoS ONE 8:e79264. doi: 10.1371/journal.pone.0079264

Ostertag, D., Annahazi, A., Krueger, D., Michel, K., Demir, I. E., Ceyhan, G. O., et al. (2017). Tryptase potentiates enteric nerve activation by histamine and serotonin: relevance for the effects of mucosal biopsy supernatants from irritable bowel syndrome patients. Neurogastroenterol. Motil. 29:e13070. doi: 10.1111/nmo.13070

Ostertag, D., Buhner, S., Michel, K., Pehl, C., Kurjak, M., Götzberger, M., et al. (2015). Reduced responses of submucous neurons from irritable bowel syndrome patients to a cocktail containing histamine, serotonin, TNF $\alpha$, and tryptase (IBS-cocktail). Front. Neurosci. 9:465. doi: 10.3389/fnins.2015.00465 
Pang, X., Boucher, W., Triadafilopoulos, G., Sant, G. R., and Theoharides, T. C. (1996). Mast cell and substance P-positive nerve involvement in a patient with both irritable bowel syndrome and interstitial cystitis. Urology 47, 436-438. doi: 10.1016/S0090-4295(99)80469-5

Paton, W. D., and Vane, J. R. (1963). Analysis of the responses of the isolated stomach to electrical stimulation and to drugs. J. Physiol. 165, 10-46. doi: 10.1113/jphysiol.1963.sp007040

Perdue, M. H., Masson, S., Wershil, B. K., and Galli, S. J. (1991). Role of mast cells in ion transport abnormalities associated with intestinal anaphylaxis. Correction of the diminished secretory response in genetically mast celldeficient $\mathrm{W} / \mathrm{Wv}$ mice by bone marrow transplantation. J. Clin. Invest. 87, 687-693. doi: 10.1172/JCI115047

Raithel, M., Winterkamp, S., Pacurar, A., Ulrich, P., Hochberger, J., and Hahn, E. G. (2001). Release of mast cell tryptase from human colorectal mucosa in inflammatory bowel disease. Scand. J. Gastroenterol. 36, 174-179. doi: 10.1080/003655201750065933

Riske, F., Hakimi, J., Mallamaci, M., Griffin, M., Pilson, B., Tobkes, N., et al. (1991). High affinity human IgE receptor (Fc epsilon RI). Analysis of functional domains of the alpha-subunit with monoclonal antibodies. J. Biol. Chem. 266, 11245-11251.

Rychter, J. W., Van Nassauw, L., Timmermans, J.-P., Akkermans, L. M. A., Westerink, R. H. S., and Kroese, A. B. A. (2011). CGRP1 receptor activation induces piecemeal release of protease-1 from mouse bone marrow-derived mucosal mast cells. Neurogastroenterol. Motil. Off. J. Eur. Gastrointest. Motil. Soc. 23, e57-e68. doi: 10.1111/j.1365-2982.2010.01617.x

Said, S. I., and Rosenberg, R. N. (1976). Vasoactive intestinal polypeptide: abundant immunoreactivity in neural cell lines and normal nervous tissue. Science 192, 907-908. doi: 10.1126/science.1273576

Schemann, M., and Camilleri, M. (2013). Functions and imaging of mast cell and neural axis of the gut. Gastroenterology 144, 698.e4-704.e4. doi: 10.1053/j.gastro.2013.01.040

Schemann, M., Kugler, E. M., Buhner, S., Eastwood, C., Donovan, J., Jiang, W., et al. (2012). The mast cell degranulator compound 48/80 directly activates neurons. PLoS ONE 7:e52104. doi: 10.1371/journal.pone.0052104

Schemann, M., Michel, K., Ceregrzyn, M., Zeller, F., Seidl, S., and Bischoff, S. C. (2005). Human mast cell mediator cocktail excites neurons in human and guinea-pig enteric nervous system. Neurogastroenterol. Motil. 17, 281-289. doi: 10.1111/j.1365-2982.2004.00591.x

Schneider, J., Jehle, E. C., Starlinger, M. J., Neunlist, M., Michel, K., Hoppe, S., et al. (2001). Neurotransmitter coding of enteric neurones in the submucous plexus is changed in non-inflamed rectum of patients with Crohn's disease. Neurogastroenterol. Motil. 13, 255-264. doi: 10.1046/j.1365-2982.2001.00265.x
Sellge, G., Laffer, S., Mierke, C., Vrtala, S., Hoffmann, M. W., Klempnauer, J., et al. (2005). Development of an in vitro system for the study of allergens and allergen-specific immunoglobulin $\mathrm{E}$ and immunoglobulin G: fcepsilon receptor I supercross-linking is a possible new mechanism of immunoglobulin G-dependent enhancement of type I allergic reactions. Clin. Exp. Allergy J. Br. Soc. Allergy Clin. Immunol. 35, 774-781. doi: 10.1111/j.1365-2222.2005. 02248.x

Stead, R. H., Dixon, M. F., Bramwell, N. H., Riddell, R. H., and Bienenstock, J. (1989). Mast cells are closely apposed to nerves in the human gastrointestinal mucosa. Gastroenterology 97, 575-585. doi: 10.1016/0016-5085(89) 90627-6

Suzuki, R., Furuno, T., Teshima, R., and Nakanishi, M. (2001). Bi-directional relationship of in vitro mast cell-nerve communication observed by confocal laser scanning microscopy. Biol. Pharm. Bull. 24, 291-294. doi: $10.1248 /$ bpb. 24.291

Torrente, F., Barabino, A., Bellini, T., and Murch, S. H. (2014). Intraepithelial lymphocyte eotaxin-2 expression and perineural mast cell degranulation differentiate allergic/eosinophilic colitis from classic IBD. J. Pediatr. Gastroenterol. Nutr. 59, 300-307. doi: 10.1097/MPG.0000000000000432

Tunçel, N., Sener, E., Cerit, C., Karasu, U., Gürer, F., Sahintürk, V., et al. (2005). Brain mast cells and therapeutic potential of vasoactive intestinal peptide in a Parkinson's disease model in rats: brain microdialysis, behavior, and microscopy. Peptides 26, 827-836. doi: 10.1016/j.peptides.2004.12.019

Wang, G.-D., Wang, X.-Y., Liu, S., Qu, M., Xia, Y., Needleman, B. J., et al. (2014). Innervation of enteric mast cells by primary spinal afferents in guinea pig and human small intestine. Am. J. Physiol. Gastrointest. Liver Physiol. 307, G719-G731. doi: 10.1152/ajpgi.00125.2014

Zoli, M., Jansson, A., Syková, E., Agnati, L. F., and Fuxe, K. (1999). Volume transmission in the CNS and its relevance for neuropsychopharmacology. Trends Pharmacol. Sci. 20, 142-150. doi: 10.1016/S0165-6147(99)01343-7

Conflict of Interest Statement: The authors declare that the research was conducted in the absence of any commercial or financial relationships that could be construed as a potential conflict of interest.

Copyright (C) 2017 Buhner, Barki, Greiter, Giesbertz, Demir, Ceyhan, Zeller, Daniel and Schemann. This is an open-access article distributed under the terms of the Creative Commons Attribution License (CC BY). The use, distribution or reproduction in other forums is permitted, provided the original author (s) or licensor are credited and that the original publication in this journal is cited, in accordance with accepted academic practice. No use, distribution or reproduction is permitted which does not comply with these terms. 